Research Article

\section{Oral Clindamycin and Metronidazole in the treatment of bacterial vaginosis in pregnant black women: Comparison of efficacy and pregnancy outcome}

\author{
ljeoma CC ${ }^{1 *}$, Nyengidiki TK ${ }^{1}$, Bassey G ${ }^{1}$, Ogu RN ${ }^{1}$, Alegbeleye $\mathrm{JO}^{1}$ \\ and Wariso $\mathrm{KT}^{2}$
}

\author{
'Department of Obstetrics and Gynaecology, University of Port Harcourt Teaching Hospital, Port \\ Harcourt, Rivers State, Nigeria \\ ${ }^{2}$ Department of Microbiology, University of Port Harcourt Teaching Hospital, Port Harcourt, Rivers \\ State, Nigeria
}

\section{Abstract}

Bacterial vaginosis (BV) is associated with adverse pregnancy outcomes with various treatment options.

Objective: To compare the efficacy and effect on pregnancy outcome of Metronidazole and Clindamycin in women with bacterial vaginosis in Port Harcourt, Nigeria.

Methodology: Randomized controlled study of 136 pregnant women diagnosed with BV at the University of Port Harcourt Teaching Hospital. A structured proforma was used to obtain socio-demographic characteristics and other relevant data. Treatment was with either oral Metronidazole or oral Clindamycin for seven days. A secondary test and evaluation of the effect on adverse pregnancy outcomes were determined. Data analysis was done using the SPSS statistical package version 22.0

Results: BV prevalence was $23 \%$, with similar cure rates with both medications. The failure rates of clindamycin and metronidazole were $10.4 \%$ and $13 \%$ respectively $(p=0.639)$. The mean gestational age at delivery in the metronidazole treated group was 38.67 weeks \pm 1.69 compared to 38.68 weeks \pm 1.64 in the oral clindamycin group $(p=0.96)$. Pre-labour rupture of membranes and preterm delivery rates with both medications were similar $(p=0.73 ;$ OR $1.3 ; 95 \% \mathrm{Cl} 0.3-4.9)$ and $(p=0.73$; OR $1.3 ; 95 \% \mathrm{Cl} 0.3-4.9)$ respectively.

Conclusion: Both medications have comparable efficacy and similar pregnancy outcomes in the treatment of bacterial vaginosis in low-risk asymptomatic pregnant Nigerian women and thus can be used interchangeably.

\section{More Information}

*Address for Correspondence: Dr. Nyengidiki Tamunomie, MBBS, FWACS, DMAS, FICS, Associate Professor and Consultant, Gynaecological Oncologist, Minimal Access Surgeon, University of Port Harcourt Teaching Hospital, Rivers State, Nigeria,

Tel: +234803109486

Submitted: 04 January 2020

Approved: 09 January 2020

Published: 10 January 2020

How to cite this article: ljeoma CC, Nyengidiki TK, Bassey G, Ogu RN, Alegbeleye JO, et al. Oral Clindamycin and Metronidazole in the treatment of bacterial vaginosis in pregnant black women: Comparison of efficacy and pregnancy outcome. Clin J Obstet Gynaecol. 2020; 3: 001-006.

DOI: dx.doi.org/10.29328/journal.cjog. 1001040

Copyright: @ 2020 ljeoma CC, et al. This is an open access article distributed under the Creative Commons Attribution License, which permits unrestricted use, distribution, and reproduction in any medium, provided the original work is properly cited.

Keywords: Bacterial vaginosisl; Clindamycin; Metronidazole; Pregnancy outcome; Port harcourt

W) Check for updates

OPEN ACCESS

\section{Introduction}

Bacterial vaginosis (BV) is a common, yet poorly understood polymicrobial vaginal disorder commonly seen in women of reproductive age [1]. BV has a particularly high prevalence in black women especially those in sub-Saharan Africa [1-4]. In South-East and North-East Nigeria, equally high prevalence of $17 \%$ and $17.3 \%$ respectively have been documented $[5,6]$. It is abnormal microbiota of the vagina characterized by a reduced number of Lactobacilli, $\mathrm{pH}$ higher than 4.5 and increased numbers of potential pathogens including but not limited to Gardnerella vaginalis, group B haemolytic streptococcus and the anaerobes Peptostreptococcus spp, Bacteroides spp and Mycoplasma hominis [7].

Approximately $50 \%-70 \%$ of women with BV are asymptomatic [1], and presentation in symptomatic women varies from increased gray-white offensive vaginal discharge intensified after intercourse and during menstruation, to lower abdominal pain and dyspareunia [8]. The diagnosis of bacterial vaginosis can be made on clinical grounds with microbiological supports such as Gram-stain based criteria (Spiegel's and Nugent) as well as Gas-Liquid chromatography [1-7]. 
In pregnant women, considerable information show that bacterial vaginosis is associated with poor pregnancy outcomes which include preterm delivery, low birth weight, perinatal and neonatal infections when untreated [1-7,9]. It is also related to obstetric complications like preterm pre-labour rupture of fetal membranes and puerperal sepsis [7]. The high prevalence and burden of BV in developing countries, make continuous efforts at determining the most effective antibiotic that gives high cure rates (or lower treatment failures), lower recurrence and lower side effect profile highly imperative.

It has been suggested that oral Clindamycin may have an advantage over oral Metronidazole due to its broader spectrum of activity but concerns about of post-therapy diarrhoea had been raised $[7,8]$. These concerns had triggered the use of clindamycin vaginal creams [10-16]. which Joesof, et al. highlighted in their work that indicated that pregnancy complications are not efficiently taken care of by the administration of clindamycin vaginal creams [17].

It is on this basis that a comparison of efficacy of oral Metronidazole against oral Clindamycin and evaluation of their effect on adverse pregnancy outcomes induced by bacterial vaginosis was undertaken in Port Harcourt, SouthSouth Nigeria.

\section{Material and methods}

This was a randomized controlled study conducted at the University of Port Harcourt Teaching Hospital, a tertiary health facility in Rivers State, Nigeria from the $1^{\text {st }}$ of July 2016 to the $31^{\text {st }}$ of December, 2016.

The study population consisted of consecutive consenting pregnant women who attended the antenatal clinics of the Teaching Hospital who were positive for bacterial vaginosis. Inclusion criteria included: women at gestational ages between 28 weeks and 32 weeks with singleton pregnancies determined from their last menstrual period or from an early ultrasound scan The following were excluded: those with a history of previous preterm labour or late miscarriage, those in whom preterm labour was induced for any obstetric or medical condition, women who did not give consent and antenatal clinic attendees with known obstetric and medical complications that could be a confounding factor for preterm labour.

The minimum sample size required for the study was calculated using the formula for clinical superiority design in a randomized controlled trial [18], were: $\mathrm{N}$ was the desired sample size, $\mathrm{Z}_{1-\alpha}$ for one-tail test at $95 \%$ Confidence interval = $1.645 ; \mathrm{Z}_{1-\beta}=0.845, \mathrm{~d}=$ Real difference between the two drugs effects and $\delta_{0=}$ A clinically acceptable margin of error assumed at $0.3, p=$ response rate of the standard treatment.

Using a previous study response rate of standard treatment [19], the minimum sample required for the study was 46.
Allowing for an attrition rate of $50 \%$ and possibly skewed distribution, the sample size for each arm of the study was increased to 68 giving a total of 136 for both arms of the study.

An average of 20 women who met the inclusion criteria and gave consent was recruited into the study daily, with an average of 100 women recruited each week. Furthermore, between three and five women daily were identified to be positive for bacterial vaginosis using Amsel's criteria [19], giving a total of about 15 to 25 women in one week. The study population was obtained in six weeks.

A Pre-structured proforma was used to obtain relevant socio-demographic and clinical data. An evaluation of any vaginal discharge was made by the investigators, noting its characteristics. Vaginal swabs were then collected from the posterior vaginal fornix for the diagnosis of bacterial vaginosis using the Amsel's criteria. All samples. The samples of all participants had a unique laboratory identification number and result sheets (Primary screening and Test of cure). The $\mathrm{pH}$ was determined using a $\mathrm{pH}$ meter. After that, a portion of the extract on the vaginal swab was placed in a small test tube $(10 \times 75 \mathrm{~mm})$ containing approximately $0.5 \mathrm{ml}$ of $0.9 \%$ normal saline $(0.9 \%$ sodium chloride in water), a whiff test was done. The result was reported as positive if there was a fishy odour following the addition of $\mathrm{KOH}$ to the vaginal sample or negative if this was absent. The presence or absence of clue cells on the vaginal sample was done following a wet mount and microscopic examination.

The clinical diagnosis of bacterial vaginosis using the Amsel's criteria required that three of the following four criteria be met: A thin homogenous vaginal discharge, vaginal $\mathrm{pH}$ greater than 4.7, an amine odour after addition of potassium hydroxide (positive whiff test) and detection of Clue cells on saline wet mount (vaginal epithelial cells with bacteria obscuring the peripheral borders). A dedicated Microbiologist handled the specimen, and a second Microbiologist double-checked each. Results were declared positive for bacterial vaginosis when there is a concordance of the results. If discordant, a third Microbiologist provides the tie-breaker. The women who were positive for bacterial vaginosis constituted the study population. Those who were negative for bacterial vaginosis were counselled on their laboratory results and excluded from the study.

The women whowere positive for BV were then randomized to receive either oral Metronidazole or oral Clindamycin to form the two arms of the study ( $\mathrm{M}$ and $\mathrm{C}$ ). Those who picked ' $M$ ' received oral Metronidazole $400 \mathrm{mg}$ three times a day for seven days while the other half that picked ' $C$ ' received oral Clindamycin $300 \mathrm{mg}$ twice daily for seven days. Unlabelled drug envelopes containing a seven-day dose of each of the medications were given to each of the study subjects. The study subjects were seen one week after completing therapy. In order, ensure compliance, a pre-treatment counselling was 
conducted explaining the significance and benefits of taking the prescribed medications. Informed consent was obtained stating their commitment to take the drugs as prescribed. Also, the patients were told to present to the clinic with the empty containers of the drugs to ascertain intake. A second vaginal swab was collected for secondary laboratory test, still using the Amsel's criteria, noting those who turned negative. The methodology employed in the initial screening and diagnosis was still used. Those who remained positive were recorded for use in calculating the percentage treatment failures (and percentage cure rate). They were then excluded from the study and re-evaluated. All the cured women were then followed up to one week after delivery. Follow up at routine antenatal appointments and via telephone communication with the subjects by the investigator was done for both groups of women throughout the study period. Any concerns raised by the study subjects including any medical or obstetric complication was noted and effectively addressed. The primary outcome was the percentage of cure rates in the two groups of women. The secondary results were the rate of preterm delivery defined as delivery at any gestational age greater than 28 weeks but less than 37 completed weeks. Other secondary outcomes included preterm pre-labour rupture of fetal membrane, low birth weight defined as absolute birth weight less than $2500 \mathrm{~g}$ and perinatal death.

Data from the structured proforma was then entered into a spreadsheet and analyzed using the SPSS 22.0 software package (IBM, Armonk, NY, USA). Chi-square test was used to compare categorical variables, while Student't' test was used to compare continuous variables between the Metronidazole and Clindamycin treatment groups and $p$ - value $<0.05$ was considered significant.

\section{Ethical approval}

Ethical approval for the study was obtained from the Ethical review board of the University of Port Harcourt Teaching Hospital with IRS number, UPTH/ADM/90/SII/ VOL./XI/385 and informed consent was obtained from all consenting women for the study.

\section{Results}

Five hundred and ninety-one pregnant women were recruited for this study. Out of these, one hundred and thirtysix women were positive for bacterial vaginosis $(23.01 \%)$ and were studied.

Table 1 illustrates the efficacy of the treatment modalities: Of the one hundred and thirty-six BV-positive pregnant women who formed the study population, sixtynine of them received oral metronidazole while sixty seven received oral clindamycin. The cumulative cure rate in the oral metronidazole group was $87 \%$ and $89.6 \%$ in the oral clindamycin group. There was no statistical difference in the efficacy of the two medications $(p=0.639)$. Nine $(13 \%)$ of the women who received oral metronidazole and seven $(10.4 \%)$ of the women in the oral clindamycin group had treatment failures following the test of cure, with an overall failure rate of $11.8 \%$.

Of the 136 pregnant women who were positive for bacterial vaginosis, 120 women were followed up to one week after delivery, after the exclusion of the 16 women who had treatment failure and thus required additional therapy.

Five (8.3\%) of the women who received oral metronidazole had preterm pre-labour rupture of membranes (PPROM), while four $(6.7 \%)$ had the same in the oral Clindamycin group. There was no statistically significant difference in the occurrence of PPROM between the two groups of treated women $[p=0.73$; OR 95\% CI $1.3(0.3-4.9)]$. Furthermore, nine (7.5\%) of the 120 women who received either oral metronidazole or oral clindamycin and followed up had preterm deliveries. [Five versus four; $\mathrm{X}^{2}=0.12 ; p=0.73$; OR 95\% CI 1.3 (0.3-4.9)].

The overall mean gestational age at delivery in the study population was $38.68 \pm 1.66$ weeks. The mean gestational age at delivery among the women in the oral metronidazole group was $38.67 \pm 1.69$ weeks, while that of the clindamycin group was $38.68 \pm 1.64$ weeks. There was no statistically significant difference $(p=0.96)$ (Table 2).

\begin{tabular}{|c|c|c|c|c|c|}
\hline $\begin{array}{c}\text { Post BV } \\
\text { treatment status }\end{array}$ & $\begin{array}{c}\text { Metronidazole } \\
\text { Group N (\%) }\end{array}$ & $\begin{array}{l}\text { Clindamycin } \\
\text { Group N (\%) }\end{array}$ & Total & $p$ - value & Chi-square \\
\hline Negative & $60(87.0)$ & 60(89.6) & $120(88.2)$ & \multirow{2}{*}{0.639} & \multirow{2}{*}{0.221} \\
\hline Positive & $9(13.0)$ & $7(10.4)$ & $16(11.8)$ & & \\
\hline Total & 69 & 67 & 136 & & \\
\hline
\end{tabular}

Table 2: Comparison of pregnancy outcomes in metronidazole vs. Clindamycin treated patients with BV.

\begin{tabular}{|c|c|c|c|c|c|}
\hline & $\begin{array}{c}\text { Metronidazole } \\
\text { Group N (\%) }\end{array}$ & $\begin{array}{l}\text { Clindamycin } \\
\text { Group N (\%) }\end{array}$ & Total (\%) & $p$ - value & OR $95 \% \mathrm{CI}$ \\
\hline $\begin{array}{c}\text { Mean GA at } \\
\text { Delivery }\end{array}$ & $38.67 \pm 1.69$ & $38.68 \pm 1.64$ & $38.68 \pm 1.66$ & 0.96 & \\
\hline $\begin{array}{l}\text { Mean Birth } \\
\text { Weight }\end{array}$ & $3.33 \pm 0.48$ & $3.38 \pm 0.45$ & $3.35 \pm 0.46$ & 0.51 & \\
\hline \multicolumn{6}{|l|}{ PPROM (\%) } \\
\hline Yes & $5(8.3)$ & $4(6.7)$ & $9(7.5)$ & 0.73 & $1.3(0.3-4.9)$ \\
\hline No & $55(91.7)$ & $56(93.3)$ & $111(92.5)$ & & \\
\hline \multicolumn{6}{|l|}{$\begin{array}{l}\text { GA at } \\
\text { Delivery }\end{array}$} \\
\hline$<37$ Week & $5(8.3)$ & $4(6.7)$ & $9(7.5)$ & 0.73 & $1.3(0.3-4.9)$ \\
\hline$\geq 37$ Weeks & $55(91.7)$ & $56(93.3)$ & $111(92.5)$ & & \\
\hline \multicolumn{6}{|l|}{ Birth Weight } \\
\hline $1.5-2.499$ & $5(8.3)$ & $3(5.0)$ & $8(6.7)$ & 0.46 & $1.7(0.4-7.6)$ \\
\hline$\geq 2.5$ & $55(91.7)$ & $57(95.0)$ & 112(93.3) & & \\
\hline \multicolumn{6}{|l|}{$\begin{array}{l}\text { Perinatal } \\
\text { Death }\end{array}$} \\
\hline Yes & $2(3.3)$ & $0(0.0)$ & $2(1.7)$ & 0.15 & \\
\hline No & $58(96.7)$ & $60(100.0)$ & 118(98.3) & & \\
\hline Total & 60 & 60 & 120 & & \\
\hline
\end{tabular}

GA: Gestational Age, PPROM: Preterm Pre-Labour Rupture Of Membranes, OR: Odds Ratio 
The mean birth weight in the study population was 3.35 $\mathrm{kg} \pm 0.46$. Among the babies born to women who received oral metronidazole, the mean birth weight was $3.33 \mathrm{~kg} \pm 0.48$ compared to the mean birth weight of $3.38 \mathrm{~kg} \pm 0.45$ among the babies of women in the oral clindamycin group. Eight $(6.7 \%)$ of all the babies born in the entire study population had birth weights less than $2500 \mathrm{~g}$. Of these, five (8.3\%) were born to women in the oral metronidazole group, while three $(5.0 \%)$ were from women in the oral clindamycin group. There was no statistically significant difference in Low birth weight among babies born to women in the two groups of treatment. $\left[p=0.46 ; \mathrm{X}^{2}=0.536 ;\right.$ OR 95\% CI $\left.1.7(0.4-7.6)\right]$.

There were two perinatal deaths in the study population, giving a perinatal mortality rate of $1.66 \%$. Both deaths were babies born to women who received oral metronidazole and died from complications of birth asphyxia. This was however not statistically significant. ( $p=0.15)$.

\section{Discussion}

The prevalence of bacterial vaginosis (BV) in this study is $23 \%$ and is in concordance with previous local studies, which noted prevalence of bacterial vaginosis among pregnant women from $17.3 \%$ to $64.3 \%$ [6,20-22]. There are striking variations in prevalence among countries, races and even groups within the same country [5,6,23-28].

The cumulative cure rate for a seven-day course of oral metronidazole five to seven days after completion of treatment has been reported to be from $84 \%$ to $96 \%[11,12,14]$. The $87 \%$ cumulative cure rate in patients given oral metronidazole also falls within this range and is thus comparable. Conversely, the $89.6 \%$ cumulative cure rate for oral clindamycin in this study is less than $94 \%$ that was reported by Greaves, et al. [19]. Most of the available published studies utilized vaginal preparations of clindamycin $[11,12,14,15,29,30]$. Because $\mathrm{BV}$ is polymicrobial, evaluating the success of the treatment is complex, and approaches to this evaluation varied widely among studies. The review of published studies of the treatment of BV by Larsson cited some issues that complicated the interpretation of treatment efficacy $[30,31]$. These include; differences in diagnostic criteria of BV, exclusion criteria for treatment, differences in the evaluation time after treatment, differences in the treatment of sex partners and differences in study designs. The review of the result obtained for the cure rate of oral metronidazole in this study with those obtained from previously reported studies clearly demonstrates these differences identified by Larsson in 1992 and could account for the variations noted $[11,12,14,15,29,30]$. However, some consistencies between this study and others still make the findings comparable. But more importantly, there is no statistically significant difference in the cumulative cure rates of oral metronidazole and oral clindamycin obtained from this study (87\% versus $89.6 \% ; p=0.639)$. Joesoef, et al. $[30,32]$ had concluded that further studies using oral clindamycin must be done before it could be considered to have an efficacy equal to those of the other recommended oral and vaginal preparations after they studied the cumulative cure rates of various regimens (oral metronidazole, clindamycin vaginal cream and metronidazole gel) in multiple studies and found no statistically significant difference $[11,12,14,15,29,30]$. They had noted that only the study by Greaves, et al. [19] at the time had used the oral preparation of clindamycin. (Ugwumadu, et al. [33] and Kiss, et al. [34], used oral clindamycin years later). More information from studies using the oral form of clindamycin was thus needed.

Considerable evidence shows that BV is associated with adverse pregnancy outcomes, as discussed in the review of literature. The American College of Obstetricians and Gynecologists (ACOG) and the Centres for Disease Control and Prevention (CDC) recommended treatment for BV included oral metronidazole $500 \mathrm{mg}$ twice daily and oral clindamycin $300 \mathrm{mg}$ twice daily both for seven days $[35,36]$. There were comparable efficacy and pregnancy outcomes for oral clindamycin and oral metronidazole in this study. There was no statistically significant difference in the occurrence of PPROM, preterm delivery, babies with low birth weight and perinatal death. This is however at variance with what Morency and Bujold, [37] recommended, that oral clindamycin be used as first-line therapy in the treatment of BV in pregnancy and concluded that the use of metronidazole alone should either be avoided in high-risk patients or combined with erythromycin but noted that more studies were needed. The variation of the two studies may be attributed to the risk profile of the two populations studied.

In further analysis of the differences between this study and that of Shennan, et al. [38], both RCTs, it is noted that Shennan et al. found that $62 \%$ of women studied delivered at gestational ages less than 37 weeks. This sharply contrasts with the $8.3 \%$ figure in this study. The mean birth weight in the study by Shennan, et al., for the women who received oral metronidazole was also significantly lower when compared with this study. About half of the women studied by Shennan, et al., had babies with LBW as against $8.3 \%$ in this study. These were all quite sharply contrasting findings. There were four perinatal deaths among the 99 babies of the women studied by Shennan, et al., (three from the 53 women who received metronidazole and one from the 46 women who received placebo), while two perinatal deaths occurred among the 120 babies in this study (both from 60 women who received metronidazole). A comparison of the perinatal deaths in this study population also had high numbers in the metronidazole group compared to the clindamycin subset. Though statistically insignificant there is need for further exploration of the possible link between these deaths and metronidazole use despite certified safety profile of the drug.

Apart from the fact that this study was conducted in lowrisk obstetric population as against the high-risk population 
studied by Shennan, et al. and Morency and Bujold, the possible racial differences in the populations studied may be a contributing factor.

Furthermore, the gestational age at screening and treatment may also be a confounding factor. In these two trials $[37,38]$, the women were screened earlier in the second trimester at gestational ages less than 22 weeks which allows for more time after treatment for weight gain by the babies and also forestalled cervical changes that could lead to PPROM and preterm delivery. The babies here should then have higher birth weights and lower preterm delivery rates. For the women in these trials who were screened and treated early in the second trimester and cured, a recurrence of the vaginal flora imbalance leading to BV days to weeks following successful treatment could also account for the findings. Conversely, in this study, the women were screened in the third trimester between gestational ages of 28 and 32 weeks. The time from treatment to delivery was thus shorter. However, it may not be out of place to also consider that this may have minimal effect on birth weight as there was a shorter time to term which may not have allowed enough time (compared to the early second trimester in the other two studies) for any effect of treatment on birth weight. The therapy also occurred late in the gestation (when compared with the other two studies) after any changes in the cervix and membranes which could predispose or lead to PPROM and preterm labour may have already taken place. In all, the differing methodologies may be contributing factors. More studies on the subject with comparable methodologies are needed.

The study is limited by the absence of directly supervised intake of the medications to ensure all doses of each medication were taken by each subject, and on time, however the patients used for the study were well motivated to taking the drugs having being counselled on the adverse effects of suboptimal treatment.

This trial attests to the fact that Oral metronidazole and oral clindamycin have comparable efficacy and similar pregnancy outcomes when used in the treatment of bacterial vaginosis in low risk asymptomatic pregnant women in the general obstetric population. At such, either of the two oral forms of the medications be used as alternatives in treating BV-positive low-risk obstetric population. However, further studies are needed to evaluate the safety profile of metronidazole in connection to treating patients with $\mathrm{BV}$ as regard perinatal deaths since similar higher rates had been observed in other studied.

\section{References}

1. Hodiwala $A B$, Koli $A$. Bacterial vaginosis (Review article). Int J Curr Microbiol App Sci. 2015; 4: 530-538.

2. Anukam K, Osazuwa E, Ahonkhai I, Ngwu M, Osemene G, et al Augmentation of antimicrobial metronidazole therapy of bacterial vaginosis with oral probiotic Lactobacillus rhamnosus GR-1 and
Lactobacillus reuteiri RC-14: randomized, double-blind, placebocontrolled trial. Microbes and Infection. 2006; 8: 1450-1454. PubMed: https://www.ncbi.nlm.nih.gov/pubmed/16697231

3. Allsworth J, Peipert J. Prevalence of Bacterial vaginosis: 2001-2004 National Health and Nutrition Examination Survey Data. Obstet Gynecol. 2007; 109: 114-120.

PubMed: https://www.ncbi.nlm.nih.gov/pubmed/17197596

4. Denney JM, Culhane JF. Bacterial vaginosis: A problematic infection from both a perinatal and neonatal perspective. Semin Fetal Neonatal Med. 2009; 14: 200-203.

PubMed: https://www.ncbi.nlm.nih.gov/pubmed/19362525

5. Adinma JI, Okwoli NR, Unaeze A, Unaeze N. Prevalence of Gardnerella vaginalis in pregnant Nigerian women. Afr J Reprod Health. 2001; 5: 50-55.

6. Ibrahim SM, Bukar M, Galadima GB, Audu BM, Ibrahim HA. Prevalence of bacterial vaginosis in pregnant women in Maiduguri, North-Eastern Nigeria. Niger J Clin Pract. 2014; 17: 154-158.

PubMed: https://www.ncbi.nlm.nih.gov/pubmed/24553023

7. Bennett P. Preterm Labour. In: Edmonds DK (ed). Dewhurst's textbook of Obstetrics and Gynaecology $8^{\text {th }}$ Edition. West Sussex: WileyBlackwell publishers. 2012; 338-355

8. Wristrom J, Noriby SR, Myhrea EB, Ekrisson S, Granstrom G, et al Frequency of antibiotics associated diarrhoea in 2462 antibiotic treated hospitalized patients, a prospective study. J Antimicrob Chemother. 2000. 47: 43-50.

PubMed: https://www.ncbi.nlm.nih.gov/pubmed/11152430

9. Rao PS, Devi S, Shriyan A, Rajaram M, Jagdishchandra K. Diagnosis of bacterial vaginosis in the rural setup: comparison of clinical algorithm, smear scoring and culture by semiquantitative technique. Indian J Med Microbiol. 2004; 22: 47-50.

PubMed: https://www.ncbi.nlm.nih.gov/pubmed/17642686

10. Leitich H, Brunbauer M, Bodner-Adler B, Kaider A, Egarter C, et al Antibiotic treatment of bacterial vaginosis in pregnancy: $A$ metaanalysis. Am J Obstet Gynecol. 2003; 188: 752-758.

PubMed: https://www.ncbi.nlm.nih.gov/pubmed/12634652

11. Ferris DG, Litaker MS, Woodward L, Mathis D, Hendrich J. Treatment of bacterial vaginosis: a comparison of oral metronidazole, metronidazole vaginal gel, and clindamycin vaginal cream. J Fam Pract.1995; 41: 443449.

PubMed: https://www.ncbi.nlm.nih.gov/pubmed/7595261

12. Andres FJ, Parker R, Hosein I, Benrubi GI. Clindamycin vaginal cream versus oral metronidazole in the treatment of bacterial vaginosis: a prospective double-blind clinical trial. South Med J. 1992; 85: 1077-1080. PubMed: https://www.ncbi.nlm.nih.gov/pubmed/1439943

13. Chen JY, Tian H, Beigi RH. Treatment considerations for bacterial vaginosis and the risk of recurrence. J Women's Health (Larchmt). 2009; 18: 1997-2004.

PubMed: https://www.ncbi.nlm.nih.gov/pubmed/20044862

14. Fischbach F, Petersen EE, Weissenbacher ER, Martius J, Hosman J, et al. Efficacy of Clindamycin vaginal cream versus oral Metronidazole in the treatment of bacterial vaginosis. Obstet Gynecol. 1993; 82: 405-410. PubMed: https://www.ncbi.nlm.nih.gov/pubmed/8355942

15. Schmitt C, Sobel JD, Meriwether C. Bacterial vaginosis: treatment with Clindamycin cream versus oral Metronidazole. Obstet Gynecol. 1992; 79: 1020-1023.

PubMed: https://www.ncbi.nlm.nih.gov/pubmed/1579299

16. Paavonen J, Mangioni C, Martin MA, Wajszczuk CP. Vaginal Clindamycin and oral Metronidazole for bacterial vaginosis: a randomized trial. Obstet Gynecol. 2000; 96: 256-260.

PubMed: https://www.ncbi.nlm.nih.gov/pubmed/10908773 
17. Joesoef MR, Schmid GP, Hillier SL. Bacterial vaginosis: a review of treatment options and potential clinical indication for therapy. Clin Infect Dis. 1999.28: S57-65.

PubMed: https://www.ncbi.nlm.nih.gov/pubmed/10028110

18. Zhong B. How to calculate sample size in Randomized Controlled Trials? J Thoracic Dis. 2009; 1: 51-54.

PubMed: https://www.ncbi.nlm.nih.gov/pmc/articles/PMC3256489/

19. Greaves WL, Chungafung J, Morris B, Haile A, Townsend JL. Clindamycin versus Metronidazole in the treatment of bacterial vaginosis. Obstet Gynaecol.1998; 72: 799-802.

PubMed: https://www.ncbi.nlm.nih.gov/pubmed/3050654

20. Ajani G, Oduyebo O, Haruna M, Elikwu C. Nugent scores of pregnant women in a tertiary institution in Nigeria. Adv Microbiol. 2012; 2: 531 536.

21. Awoniyi AO, Komolafe OI, Bifarin 0 , Olarinde 0 . Bacterial vaginosis among pregnant women attending a primary health centre in Ile-Ife Nigeria. Global Adv Res J Medicine Med Sci. 2015; 4: 57-60.

22. Olowe OA, Makanjuola OB, Adekanle DA. Prevalence of vulvovaginal candidiasis, trichomoniasis, and bacterial vaginosis among pregnant women receiving antenatal care in South-Western Nigeria. Eur $\mathrm{J}$ Microbiol Immunol. 2014; 4: 193-197.

PubMed: https://www.ncbi.nlm.nih.gov/pubmed/25544891

23. Demba E, Morison L, Van der Loeff MS, Awasana AA, et al. Bacterial vaginosis, vaginal flora patterns, and vaginal hygiene practices in patients presenting with vaginal discharge syndrome in Gambia, West Africa. BMC Infect Dis. 2005; 5: 12

PubMed: https://www.ncbi.nlm.nih.gov/pubmed/15757510

24. Morris MC, Rogers, PA, Kinghorn GR. Is bacterial vaginosis a sexually transmitted infection? Sex Transm Infect. 2001; 77: 63-68.

PubMed: https://www.ncbi.nlm.nih.gov/pubmed/11158694

25. Holzman C, Leventhal JM, Qiu H, Jones NM, Wang J, et al. Factors linked to bacterial vaginosis in non-pregnant women. Am J Public Health. 2001; 91: 1664-1670.

PubMed: https://www.ncbi.nlm.nih.gov/pubmed/11574333

26. Govender L, Hoosen AA, Moodley J, Moodley P, Sturm AW. Bacteria vaginosis and associated infections in pregnancy. Int $\mathrm{J}$ Gynaecol Obstet. 1996; 55: 23-28.

PubMed: https://www.ncbi.nlm.nih.gov/pubmed/8910078

27. Thomas T, Choudhri S, Kariuki C, Moses S. Identifying cervical infection among pregnant women in Nairobi, Kenya: Limitations of risk assessment and symptom-based approaches. Genitourin Med. 1996; 72: 334-338.

PubMed: https://www.ncbi.nlm.nih.gov/pubmed/8976848
28. Schneider H, Coetzee DJ, Fehler HG, Bellingan A, Dangor $Y$, et al Screening for sexually transmitted diseases in rural South African women. Sex Transm Infect. 1998; 74 Suppl 1: S147-152.

PubMed: https://www.ncbi.nlm.nih.gov/pubmed/10023366

29. Hanson JM, McGregor JA, Hillier SL, Eschenbach DA, Kreutner AK, et al. Metronidazole for the treatment of bacterial vaginosis. A comparison of vaginal gel vs. oral therapy. J Reprod Med. 2000; 45: 889-896. PubMed: https://www.ncbi.nlm.nih.gov/pubmed/11127100

30. Joesoef MR, Schmid GP, Hillier SL. Bacterial Vaginosis: Review of treatment Option and potential clinical indication for therapy. Clin Infect Dis .1999; 28(Suppl1): S57-65.

PubMed: https://www.ncbi.nlm.nih.gov/pubmed/10028110

31. Larsson PG. Treatment of bacterial vaginosis. Int J STD AIDS. 1992; 3 : 239-247.

PubMed: https://www.ncbi.nlm.nih.gov/pubmed/1504154

32. Joesoef MR, Schmid GP. Bacterial vaginosis: a review of treatment options and potential clinical indications for therapy. Clin Infect Dis. 1995; 20(suppl 1): S72-79.

PubMed: https://www.ncbi.nlm.nih.gov/pubmed/10028110

33. Ugwumadu A, Manyonda I, Reid F, Hay P. Effect of early oral clindamycin on late miscarriage and Preterm delivery in asymptomatic women with abnormal vaginal flora and bacterial vaginosis: a randomized controlled trial. Lancet. 2003; 361(9362): 983-988.

PubMed: https://www.ncbi.nlm.nih.gov/pubmed/12660054

34. Kiss $H$, Petricevic $L$, Husslein P. Prospective randomized controlled trial of an infection screening programme to reduce the rate of preterm delivery. BMJ. 2004; 329(7462): 371.

PubMed: https://www.ncbi.nlm.nih.gov/pubmed/15294856.

35. Centers for Disease Control and Prevention, CDC. Division of STD Prevention: 2017.

www.cdc.gov/std.2010.CDCSTDtreatmentguidelines.www.cdc.gov/ std/treatment/2010.

36. ACOG Committee on Practice Bulletins--Gynecology. Clinical management guidelines for Obstetrician-Gynaecologists, Number 72, May 2006: Vaginitis. Obstet Gynecol. 2006; 107: 1195-1206. PubMed: https://www.ncbi.nlm.nih.gov/pubmed/16648432

37. Morency AM, Bujold E. The effect of second-trimester antibiotic therapy on the rate of preterm birth. J Obstet Gynaecol Can. 2007; 29: 35-44. PubMed: https://www.ncbi.nlm.nih.gov/pubmed/17346476

38. Shennan A, Crawshaw S, Briley A, Hawken J, Seed P, et al. A randomised controlled trial of metronidazole for the prevention of preterm birth in women positive for cervicovaginal fetal fibronectin: the PRIMET Study. Br J Obstet Gynaecol. 2006; 113: 65-74. PubMed: https://www.ncbi.nlm.nih.gov/pubmed/16398774 